\title{
Aspects of the Evolution of Secondary Education Development in South Muntenia Region of Romania in the Last Decades
}

\author{
Loredana Păunescu ${ }^{1}$ \\ ${ }^{1}$ Lecturer economist, Petroleum-Gas University, Ploiesti, Romania \\ E-mail: loredana.paunescu@yahoo.com
}

\begin{abstract}
In terms of sustainable development and improving living standards at the local and regional level, secondary education plays an important role. The main objective of the study was to identify the characteristics of the evolution of secondary education development in South-Muntenia region and the counties included in this region for the last 25 years. Its efficiency is also evaluated in terms of the number of Baccalaureate graduates awarded with a degree, compared to the high school level graduates in each county. The paper highlights the similarities and disparities between districts, on equipment and efficiency of secondary education in this region.

Keywords: education, secondary education, development regions, students' progress, the curriculum in the educational units.
\end{abstract}

\section{Introduction}

The sustainable development of human society, the development of technologies for environmentally friendly production, information technology and communication of a society based on knowledge are the main goals of the utmost importance for long-term growth of quality of life, both at EU level and in Romania and with regard to regional development [1]. In these circumstances, education is a fundamental prerequisite for poverty reduction and increased social welfare at both the local and regional levels [2]. In terms of society, the free movement of labour, education and skills acquired are factors which contribute to building and maintaining a functional labour market [3] and ensure a standard of living adequate for the human communities.

On the other hand, the social, environmental quality and social characteristics to educate and form the young population is an important factor of transition for the school-age population (and not only) from one level of education to another [4]. This forms a feedback loop that can lead local and regional communities towards sustainable living standards. Development and performance depend on the quality of educational stakeholders in the process. Firstly, we should consider the quality of teachers. Their attitudes and their involvement in both urban and rural areas, are key factors of educational performance [5, 6].

Quality and performance of the educational systems depend on the quality of education infrastructure. In this regard, the development in the current telecommunication, computer equipment with high performance in schools is vital [7]. Last, but not least, the quality of education depends, on one hand, on the attention of the rulers of this area [8] and, on the other hand, on the quality of management at regional, county and local levels [9]. 
Another influence on sustainable development is the number and percentage of students enrolled in various levels of education, including the level of high school secondary education. In Romania, high school secondary school population decreased continuously. Thus, if in 1995 the number of students was 644 085, in 2010 there were only 523362 students, and in 2018-447026 students [10]. After 2010, the gross enrolment rate in secondary education has been steadily decreasing, from $96.7 \%$ in the school year 2010/2011 to $96.0 \%$ in the school year 2011/2012; school year 2015/2016 reached only $85.6 \%$ [11]. At the regional level, the direct effect of demographic developments, is generated by the following: reducing the birth rate, natural growth and external migration of the population of Romania, adjusted net enrolment rate in the school year 2011/2012, recording the lows in the North East $(69.1 \%)$ and South-Muntenia (71.6\%), corresponding to their level of economic development [12]. Given these aspects, the purpose of this article was to analyse the evolution and performance of secondary education development in South-Muntenia region in the recent decades.

\section{Methodology and key steps}

The analysis of the secondary education development in South-Muntenia region was performed on the data series on the number of students [10] and high school teachers in the region and within the seven counties [13] contained therein, on equipping high school students with personal computers [14]. Also, in order to obtain a qualitative evaluation of the development of high school education in this region's development there were included in the analysis data sets on the number of high school graduates [15] and graduates with a Baccalaureate degree [16] both at regional and at county levels. For this were used and analysed five indicators. The codes and their meanings are shown in Table 1.

Table 1. The main variables used

\begin{tabular}{|c|c|c|}
\hline Indicator & Signification & Units \\
\hline BAC & Graduates with a baccalaureate degree. & number \\
\hline TS & Teaching staff & number \\
\hline PC & Personal computers & number \\
\hline STD & Students & number \\
\hline HSG & High school graduates & number \\
\hline
\end{tabular}

In this paper the developments are analysed according to five variables (identifiers) for the periods for which data were available. Thus, analysis of the number of students enrolled in high school and staff related, and the number of high school graduates is conducted during 1995-2018 and the evolution of the number of PCs during 2001-2018. Regarding the graduates with a Baccalaureate degree, the serial data is much shorter, covering only the period from 2010 to 2017. This is a consequence of the changes to complete the Baccalaureate, which induced a discontinuity in the data series.

\section{The case study. Detailed analysis}

In the analysed periods regarding secondary education, both in terms of the number of students and teachers involved in the education process experienced periods with different characteristics determined on the one hand, by the rate of birth, and on the other hand, by the characteristics of social media and legislation at different points in time.

\subsection{Students, teachers, IT resources}

In the South-Muntenia region, during 1995-2018, the evolution of the number of students enrolled in high school (STD), is characterized by three periods with slightly different characteristics (Figure 1). The first period was between 1995 and 2000. At the regional level, in 2000 compared with 1995, the number of students enrolled in secondary education was lower with 18177 students (a 
decrease of $16.22 \%$ ), due, in particular, to reducing birth rates in the period 1982-1986, as well as changing attitudes towards education in the next period of 1989. The descendent trend is registered at the level of the region and its counties. The same downward trend is recorded in each of the seven counties. In terms of numbers, the largest decreases were recorded in Prahova (5669 students) and Arges (3858 students). In relative numbers, the largest reduction was recorded in Giurgiu (24.87\%). This was followed by Prahova (19.42\%), Teleorman (15.82\%) and Ialomita (15.35\%).

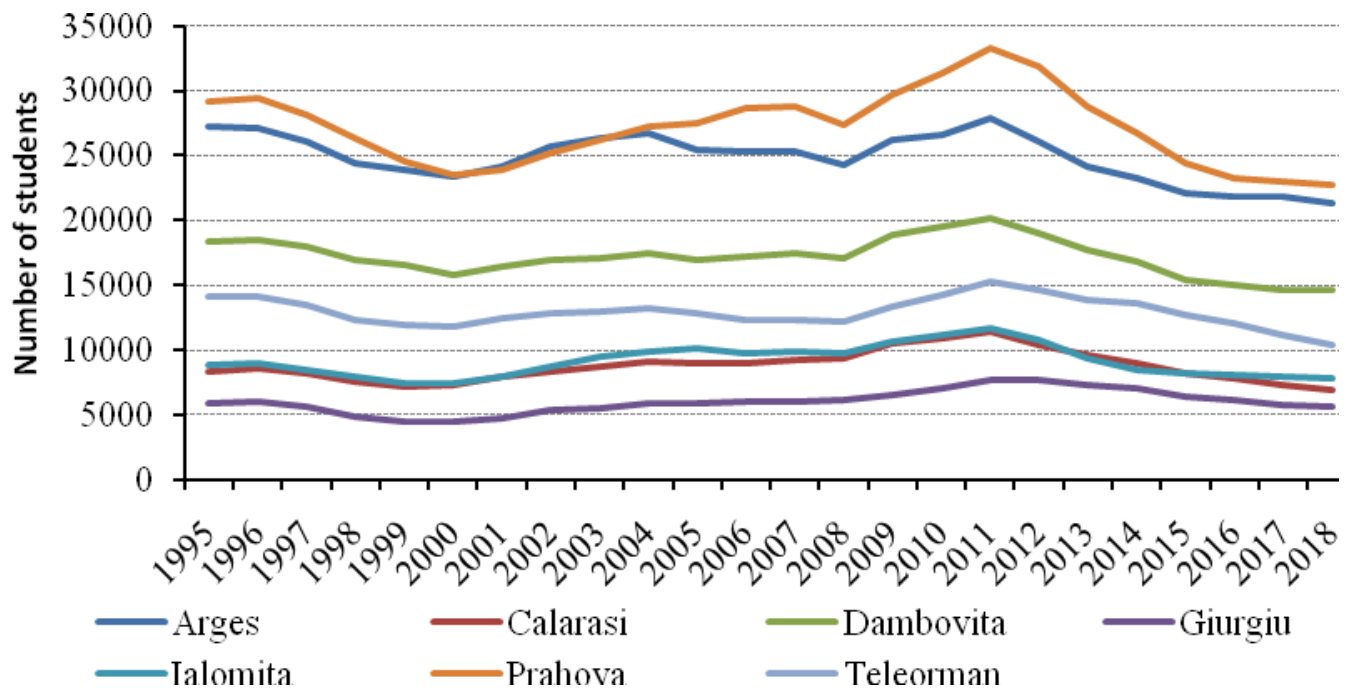

Figure 1. Evolutions of the number of students enrolled in secondary high school in the counties from the South Muntenia region during 1995 until 2018 period

The second period (2000-2011) is characterized by the relative increase in the number of students in the secondary high school education in the South region. At the regional level in 2011, compared to 2000 in the education school enrolment there were 127412 students, with 33525 more than in 2000 (an increase of $35.71 \%$ ). In numerical terms, the highest increases were registered in Prahova (9732 students), Arges (4438 students) and Dambovita (4336). In relative numbers, the highest increases were recorded in Giurgiu (72.89\%) and Calarasi (57.01\%). After 2011 the number of students registered for secondary school decreased continuously. At the regional level, the decrease was continuous and linear, described by a model of the following form:

$$
S T D(t)=129622.4-5576.11 \cdot t+\varepsilon, \quad t_{2011}=1
$$

Given that the level of significance of the test $F($ Sig.F $=0.00)$ and $R 2=0.951$, that model (1) is statistically significant and accurately describes the evolution of the number of students registered for secondary school during 2011 and 2018. At county level, more than one third reduction in the number of students registered for secondary school were recorded in Călăraşi $(39.93 \%)$ and Ialomita (33.22\%). Another characteristic of the number of pupils registered for secondary school development in South-Muntenia region is that while during 2000-2011 there were increases, however, at the end of period, in 2018, their number was lower than in 1995, both at regional level and in each county. The evolution of the teachers is slightly different to the number of pupils (Figure 2). At the regional level, the development of a number of high-school teacher is characterized by a downward expressed by the linear model of the form:

$$
S T D(t)=8856.56-62.73 \cdot t+\varepsilon, \quad t_{1995}=1
$$


If the model (2) the significance test F (Sig.F $=0.00$ ) leads to the conclusion that it is statistically important. Meanwhile, although the determination coefficient $\mathrm{R} 2=0.595$, we believe that this model describes quite well the evolution of teaching staff numbers throughout the period.

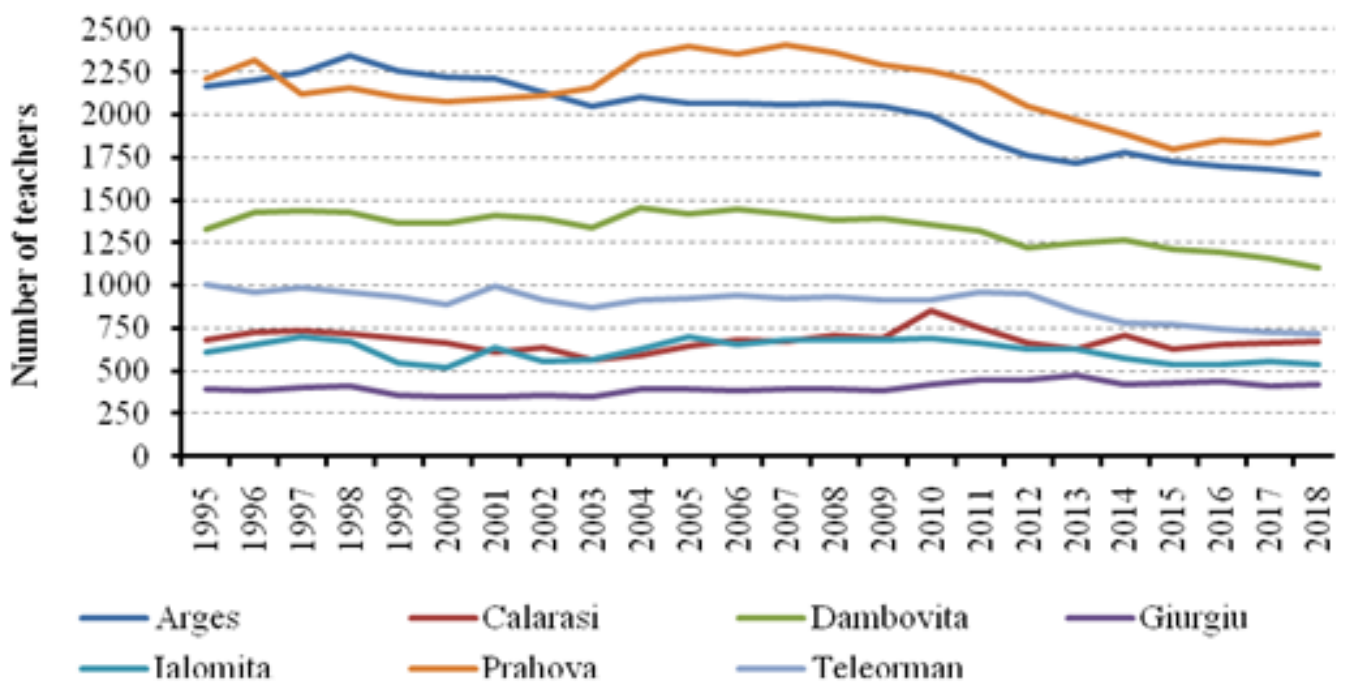

Figure 2. Evolutions of the number of teachers enrolled in secondary high school in the counties from the South Muntenia region during 1995 until 2018 period

At the county level there have been two trends, one which was characterised by a decline and another by an increase in the number of teachers. Consequently, while counties such as Arges, Prahova, Teleorman and Dambovita, the number of teachers in secondary education fell by an average of values between 10 and 22 persons, in the counties Calarasi and Ialomita the number was constant, and Giurgiu slightly increased.

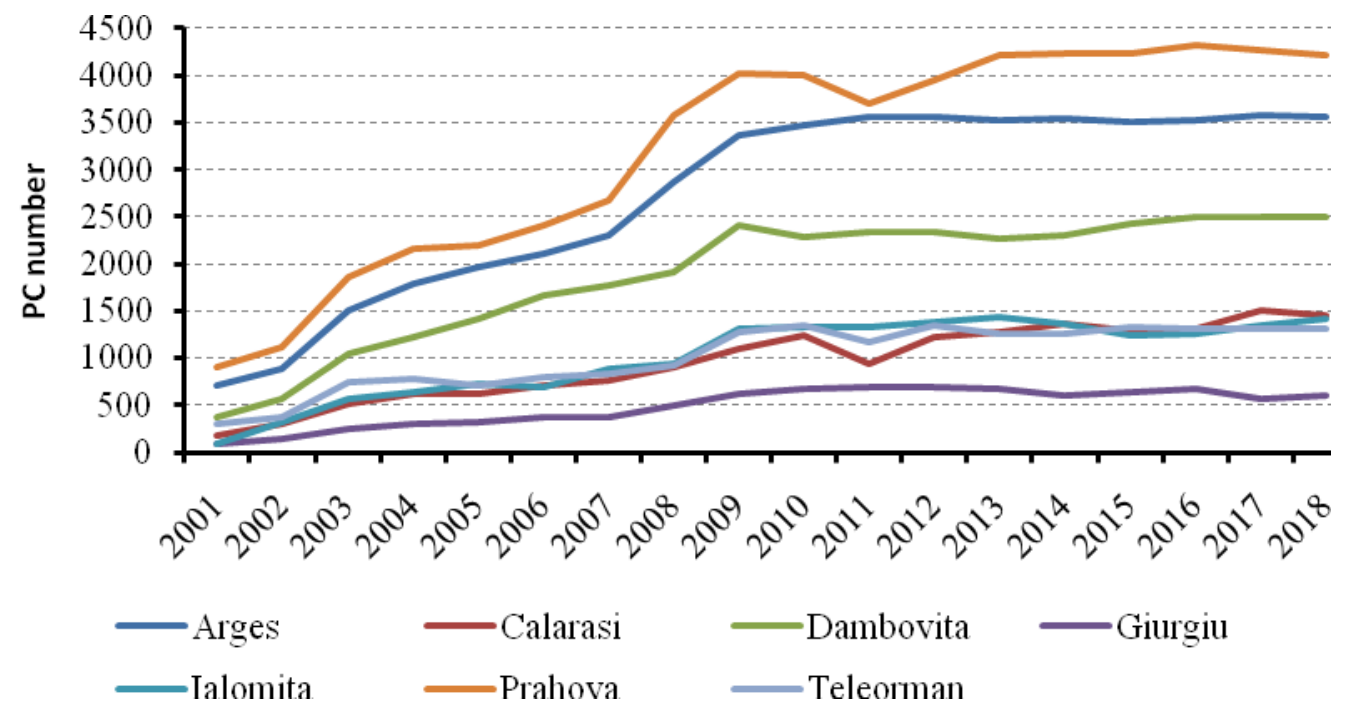

Figure 3. Evolutions of the number of PC in secondary high school in the counties from the South Muntenia region during 1995 until 2018 period 
Among the superstructure fundamental to the quality of education provided in schools in general, and high schools, in particular, there is the ICT infrastructure. The development of these media and improved accessibility and their usefulness has made after 2000, the number of high schools to grow significantly in a first period (Figure 3) then tending to stabilize. In the South-Muntenia region, changes in the number of computers in schools, in the period 2001-2018 can be described by a model of the form:

$$
P C(t)=1058.6+5083.4 \cdot \ln (t)+\varepsilon, \quad t_{2001}=1
$$

For the model (3), according to the significance level of the test $F$ (Sig.F $=0.000$ ), and the coefficient of determination $\mathrm{R} 2=0.943$, it is clear that the model is highly statistically noteworthy and describes the evolution of the number of computers in high schools that are in the South -Muntenia region. Analysis of the number of computers available in schools, in the county, revealed that both in 2001 and 2018, most of them are in Prahova $(34.04 \%$ and $28.06 \%, 2018)$, Arges $(26.86 \%$ and 23.6 $\% \%, 2018)$ and Dâmboviţa $(18.83 \%$ and $16.56 \% \%, 2018)$, and the least in the region Giurgiu (3.5\% and $4.1 \% \%, 2018)$. A clear and conclusive ICT infrastructure development in South-Muntenia region is the number of pupils per PC. Thus, if in 2001, a PC was available for 37 high school students, in 2018 the number drops to 6 students per PC, situation underlined in the model of the following form:

$$
P C(t)=31.62-9.69 \cdot \ln (t)+\varepsilon, \quad t_{2001}=1
$$

The 4-th model is also statistically significant $(\mathrm{Sig} . \mathrm{F}=0.00)$ and describes the evolution of the number of high school students per PC $(\mathrm{R} 2=0.902)$ in the period 2001-2018. Similar evolutions are recorded at county level except that the stabilizing trend that highlights the differences on the level of equipment of high school with the PC on the one hand, and on the other hand, the discrepancies existing in 2001 also maintaining in 2018. As a result, in 2001, although at regional level PC is back to 37 students in Ialomita their number reached 87 (over two times higher) in Giurgiu was 51 students in Dâmbovița 45, and Calarasi, Teleorman 42 students, in Prahova County, one PC was used by 27 students. Although during 2001-2018 the number of PCs in high schools in the South region increased significantly, some discrepancies maintained so that, while in Prahova and Calarasi one PC was used by 5 students in Teleorman their number reached 8, in Giurgiu county and a PC was available for 9 students enrolled in high school.

\subsection{Efficiency aspects of high school education in the South-Muntenia}

The number of graduates of secondary high school education (HSG) in South Muntenia development region during 1995-2017 followed, to some extent, changes in the number of students enrolled in high school in the same period specifying that it covers only the last year of high school graduates, while the number of students enrolled in high school (STD) includes all high-school students. The difference is, however, that the number (Figure 4) is more uncertain because of the changes over the period of evolution of the birth, of structural changes, the requirements of the labour market on the level of training and the level exigency. But here distinguish three periods. 1995-2001 period aims on a new scale, type downward trend in the number of students enrolled in high school in that period. For the mentioned counties, the number of graduates of secondary education in 2001 was lower than in 1995 to 1790 in Arges (a decrease of 15.75\%), with 1638 in Prahova (a decrease of 12.19\%), with 812 in Dambovita (a reduction of 12.18\%), with the Teleorman 742 (a decrease of 13.17\%), with 433 Giurgiu (a $15.62 \%$ reduction) and $11 \%$ Călăraşi and Ialomiţa. The second period (2001-2011) is one of oscillation around a trend slightly upward, so that the number of high school graduates in 2011 at regional level with 6701 graduates was higher than in 2001 (an increase of 33.75\%), exceeding by 657 the number of graduates in 1995. at the county level, the level in 2011 was higher than in 2001 at between 22.59\% in Arges county, and 79.39\% in Giurgiu. Except Arges County, in all other counties Muntenia Sud, the number of high school graduates was higher than in 1995. 


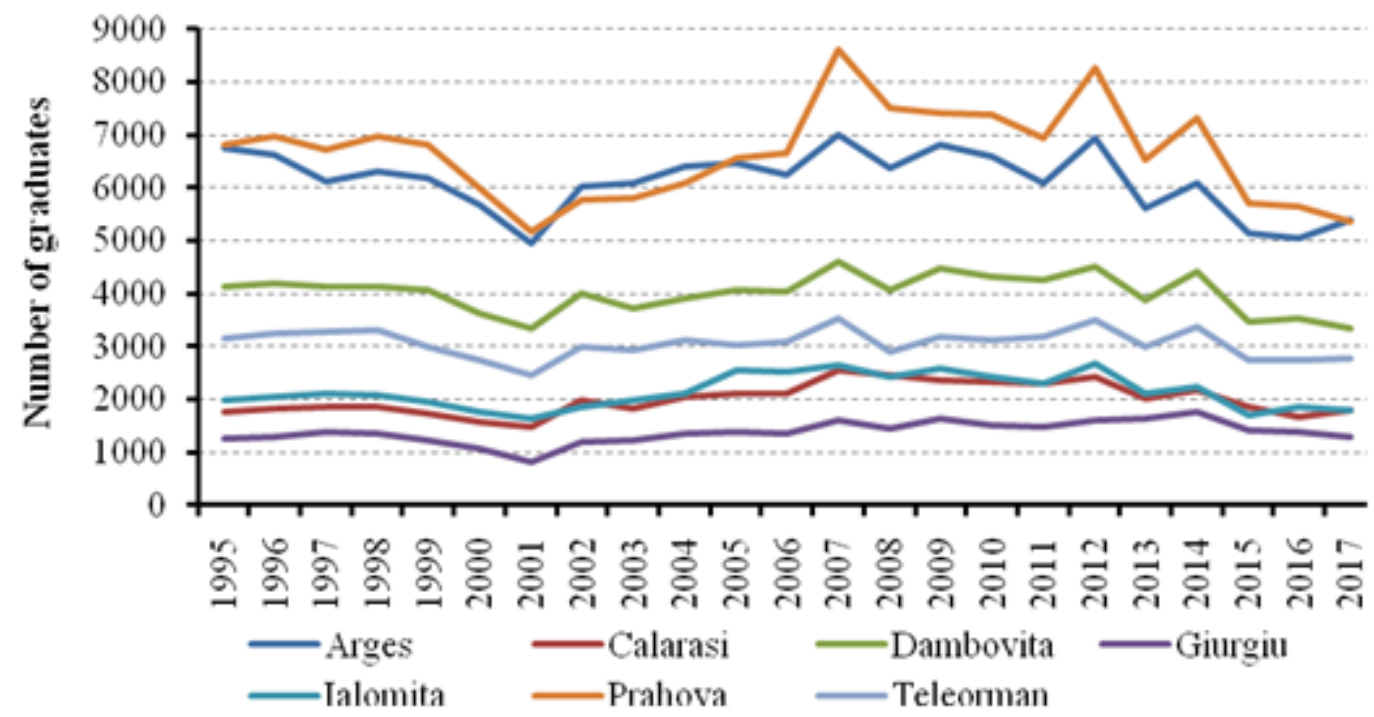

Figure 4. Evolutions of the number of graduates in secondary high school in the counties from the South Muntenia region during 1995 until 2018 period

In the third period (2012-2017) it has been a continuous decline, therefore, in 2017, at regional level, the number of graduates was lower with 4846 than in 2011 (a decrease of 18.25\%). In the counties, the number of graduates has decreased between $11.43 \%$ in Argeş, and $22.85 \%$ in the Prahova region.

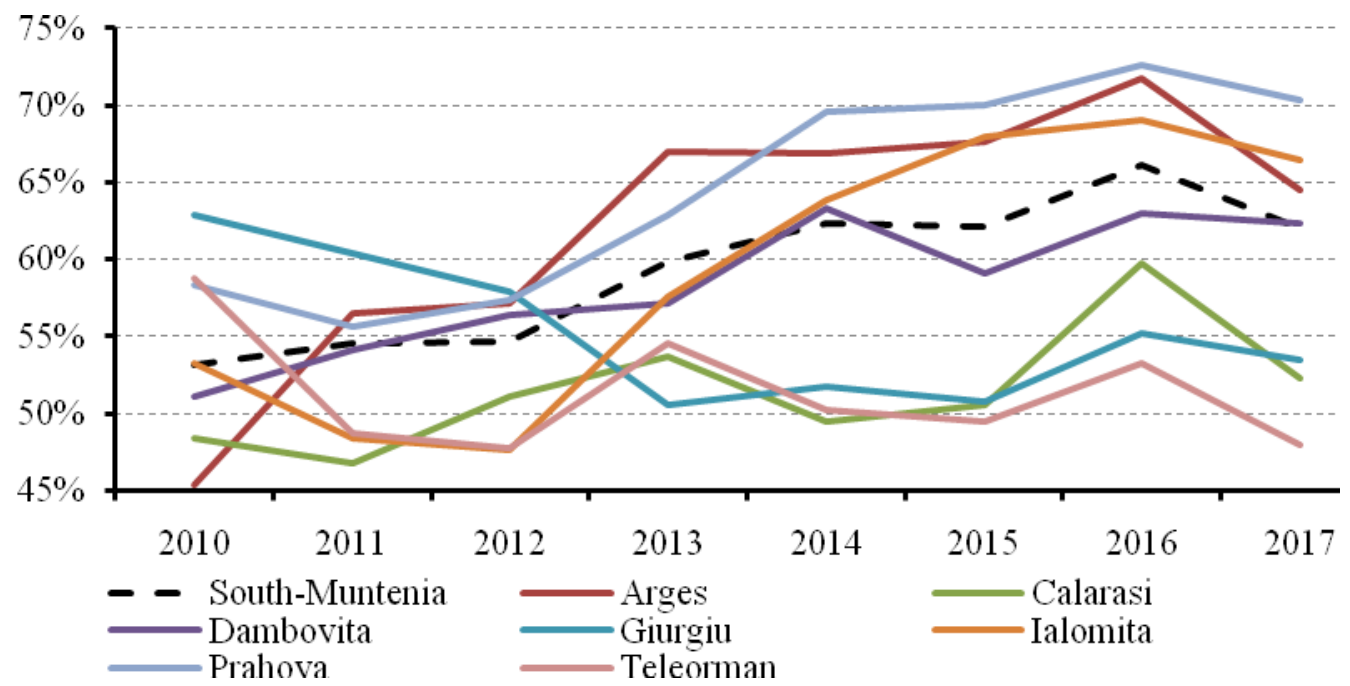

Figure 5. Evolutions of the percentage of graduates with a Baccalaureate degree in secondary high school in the counties from the South Muntenia region during 1995 until 2018 period

The most conclusive indicator of the efficiency of secondary education is the number and percentage of Baccalaureate graduates awarded with degree. In this respect, the measures taken by the Ministry of Education since 2010, on the organization of the Baccalaureate national exam, have highlighted both similarities and differences between counties in this regard. The development of the number of graduates with a Baccalaureate Degree, in the region of South-Muntenia and at the county 
levels (Figure 5) highlights a regional upward trend based on a percentage of $53.13 \%$ in 2010 to $66.07 \%$, in 2016, followed by a slight decrease of 4.01 percentage pointed in 2017 .

At the county level in the last four years, with shares above the average level of the region were Prahova, Arges and Ialomita, and in 20017 Dambovita. By contrast, there are the counties Calarasi, Giurgiu and Teleorman. Analysing the evolutionary trajectories of the percentage of Baccalaureate graduates with a degree shows that disparities between counties, from this point of view is troublesome. Thus, in 2012, in Prahova the percentage of graduates with a Baccalaureate degree was $57.36 \%$ and in Teleorman county was $47.78 \%$ (a difference of 6.96 percentage points), in 2017 the difference between the percentages of Graduates with a Baccalaureate degree in the two counties reached 22.40 percentage points. Significant differences between Prahova and Calarasi counties are highlighted (18.1 percentage points) and Giurgiu (16.85 percentage points). It thus forms, in the South-Muntenia, two groups of counties efficiency opposite trends of high school which, if not corrected, can lead to lasting damage to regional development in this region.

\section{Conclusions}

The results of the research confirmed the counties in the region of South-Muntenia development issues raised in the first part, however, they also highlight a number of peculiarities. A first difference between counties is given by the weight reduction in the number of students enrolled in high school. Giurgiu County was $24.88 \%$, in Prahova County of $19.24 \%$, and on the opposite is Calarasi County where registered numbers were only $12.19 \%$. Reducing the number of pupils enrolled in secondary education increased in the period 2011-2018, the most significant being in Călăraşi $(39.93 \%)$ and Ialomita $(33.22 \%)$.

In terms of the teaching staff, although at regional level, between 1995-2018 the number of teachers has decreased annually by an average of 61 people in the counties have registered two trends, one of decrease, and other growth. While in counties such as, Arges, Prahova, Teleorman and Dambovita, the number of teachers in secondary education fell by an average of values between 10 and 22 people in the counties Calarasi and Ialomita the number was approximately constant, and Giurgiu County recorded a slight increase.

Although after 2000 the number of PC raised significantly, discrepancies are still maintained so that, while in Prahova and Calarasi a PC is used by 5 students in Teleorman their number reaches 8 and in Giurgiu a PC is used by 9 students enrolled in high school. An important conclusion is also that, although in the South-Muntenia region there is an increase in the number of graduates with a Baccalaureate degree out of the total graduates high school education, there are still evident the differences between the group of Prahova, Arges, Dambovita and Ialomita counties that weights the degree of graduation above the average level of the region (61.98\% in 2017) and the group Giurgiu, Calarasi and Teleorman counties which weights far below the average percentage of graduation.

Evolutions in the health status of the population, such as restrictions aimed at reducing the degree of infection of the population with the new coronavirus (Covit-19), have and will have implications for education in the analysed development region. Given this fact, an important direction for future research is to identify the impact of Covit-19 on the school population taking into account local particularities regarding the level of development of electronic communications.

\section{References}

[1] Zaharia M. (2019).Considerations on the Evolutions and Particularities of the Human Development Index in European Countries, Journal of Research and Innovation for Sustainable Society (JRISS). Volume 1, Issue 1, 2019. http://jriss.4ader.ro/pdf/201901/15_JRISS_1-114-123.pdf

[2] Urean C. A. (2017), An Overview of the Romanian Education System, Annals - Economy Series, 3, issue, p. 146-153. 
[3] Masuda K., Sakai Y. (2018), Secondary education and international labor mobility: Evidence from the free secondary education reform in the Philippines, CEI Working Paper Series, Center for Economic Institutions, Institute of Economic Research, Hitotsubashi University. No 2018-5.

[4] Emer S. (2016), Social Relationships and the Transition to Secondary Education, The Economic and Social Review, 47, issue 4, p. 451-476.

[5] Logofatu M., Stefanescu C. (2016), Particularities Of Human Resource Management in the Romanian Secondary Education, Annals - Economy Series, 6, issue , p. 77-84.

[6] Mavric F. (2006), Women in Secondary Education Management, Management, 1, issue 1, p. 7991.

[7] Zaharia M., Patrascu A., Tanasescu A. (2016), Cluster Analysis of PC Endowment in PreUniversity Education at Romanian Counties Level, Annals - Economy Series, 2 Special, issue , p. 191-195.

[8] Pribac I. L. (2012), Education - a factor in the economic growth. Romania's case, Annals Economy Series, 1, issue, p. 146-149.

[9] Calinescu I., Costache G., Frasineanu C. (2018), Quality Management in the Romanian Upper Secondary Education: A Different Internal and External Perspective, Proceedings of the International Management Conference, 12, issue 1, p. 957-967.

\section{Statistical data sources}

[10] National Institute of Statistics of Romania (2020) SCL103E, Populaţia şcolară pe niveluri de educaţie, medii de rezidenţă, macroregiuni, regiuni de dezvoltare şi judeţe, http://statistici.insse.ro:8077/tempo-online/\#/pages/tables/insse-table. Accessed February 2, 2020.

[11] Ministerul Educatiei Nationale (2016). Raport privind starea învătământului preuniversitar din România. Guvernul României, Ministerul Educatiei Nationale, p. 22.

https://www.edu.ro/sites/default/files/_fi\%C8\%99iere/Minister/2017/transparenta/Stare\%20preuniv\%2 02016.pdf

[12] Costache L (coord. UNICEF), Fartusnic C (coord), Jigau M. (coord), (2014), Participarea la educatie în învătământul secundar superior. UNICEF România, Institutul de Stiinte ale Educatiei p.9-10, 22, http://www.unicef.ro/wp-content/uploads/Raport-OOSC-InvatamantSecundar-Superior_final.pdf,

[13] SCL104E, Personalul didactic pe niveluri de educaţie, medii de rezistenţă, macroregiuni, regiuni de dezvoltare şi judeţe, http://statistici.insse.ro:8077/tempoonline/\#/pages/tables/insse-table. Accessed February 10.2020.

[14] SCL112C, PC-uri pe niveluri de educaţie, macroregiuni, regiuni de dezvoltare şi judeţe, http://statistici.insse.ro:8077/tempo-online/\#/pages/tables/insse-table. Accessed February 10, 2020

[15] SCL109B, Absolvenţi pe niveluri de educaţie, forme de învăţământ, macroregiuni, regiuni de dezvoltare şi judeţe, http://statistici.insse.ro:8077/tempo-online/\#/pages/tables/insse-table. Accessed February 10, 2020

[16] SCL109G, Numărul elevilor care au promovat examenul de bacalaureat, pe sexe, macroregiuni, regiuni de dezvoltare şi judeţe, http://statistici.insse.ro:8077/tempoonline/\#/pages/tables/insse-table. Accessed February 10, 2020. 